\title{
Recruitment of the brown mussel Perna perna onto natural substrata: a refutation of the primary/ secondary settlement hypothesis
}

\author{
T. A. Lasiak, T. C. E. Barnard \\ Department of Zoology, University of Transkei, Private Bag X1, UNITRA, Umtata 5100, South Africa
}

\begin{abstract}
The pattern of recruitment of the brown mussel Perna perna on an exposed rocky shore on the southeast coast of South Africa between March 1991 and March 1992 is reported. The densities and population size structures of plantigrades associated with 2 natural substrata, filamentous algae and established mussel clumps, are contrasted. Mussels of $<500 \mu \mathrm{m}$ shell length were present throughout the study period, but peaked in abundance during the winter months (June to September). Although the density of these early plantigrades varied with both sampling date and site, type of substratum had no effect. Late plantigrades, mussels of $>0.5$ to $3.5 \mathrm{~mm}$ shell length, reached peak abundance amidst mussel clumps in winter as opposed to spring/early summer on algal turf. Sampling date, site and type of substratum all influenced the density of late plantigrades. The size distributions of the recruits found in association with the 2 substrata differed significantly on 4 of the 11 sampling dates. The recruitment pattern of $P$. perna does not, therefore, conform with the generally accepted primary/secondary settlement hypothesis. The observed pattern indicates direct settlement of larvae from the plankton onto adult beds in addition to temporary attachment on filamentous algae. The relatively low intensities of recruitment observed, compared with those of other mytilids, may explain such anomalous attributes of P. perna as its lack of competitive dominance and low resilience to disturbance.
\end{abstract}

KEY WORDS: Mussel - Rocky shores - Recruitment · Settlement

\section{INTRODUCTION}

The settlement and recruitment processes of mytilid bivalves have received considerable attention. Early studies by Maas Geesteranus (1942), Verwey (1952) and De Blok \& Geelen (1958) indicated that post-larval Mytilus edulis attach and detach themselves from the substratum several times. Bayne (1964) subsequently postulated that mussel larvae settle initially on filamentous substrata; after a period of growth they then detach and enter into a secondary pelagic phase. During the latter, so-called bysso-pelagic migration phase, the plantigrades may attach to, and detach from, several filamentous substrata prior to selecting sites of permanent attachment on established mussel beds. Until recently this primary and secondary settlement hypothesis was assumed to be universally applicable. There is, however, growing evidence that, in some mytilid populations, early plantigrades forgo the initial growth phase on filamentous substrata and settle directly onto adult mussel beds (McGrath et al. 1988, Cáceres-Martinez et al. 1993).

Bayne's (1964) observations clearly pertain to what is now defined as recruitment, that is, the process of successful colonization after a specified period of time, during which some degree of post-settlement mortality may have occurred. Nowadays the term settlement is reserved for the process whereby larvae come in contact with, and permanently attach to, the substratum, a process which may encompass metamorphosis (Seed \& Suchanek 1992).

Despite extensive commercial cultivation and intense exploitation of natural stocks, relatively little is known about patterns of settlement and recruitment of mytilids in southern Africa (du Plessis 1977, Griffiths 1981, Crawford \& Bower 1983). Recent evidence of the 
adverse impact of subsistence gatherers on stocks of the brown mussel Perna perna along the Transkei coast, South Africa (Siegfried et al. 1985, Lasiak \& Dye 1989, Lasiak 1991), has prompted interest in methods of enhancing natural productivity. The primary objective of the present investigation was to obtain information on the onset and duration of recruitment onto natural substrata. Such information is considered a prerequisite for further studies on the feasibility of using artificial substrata to encourage recruitment in depleted areas (Lasiak \& Barnard unpubl.). Concomitant comparisons of the abundance and size composition of plantigrades on filamentous algae and established mussel beds also provided an opportunity to contribute to the current debate on the universal applicability of the primary and secondary settlement hypothesis.

\section{MATERIALS AND METHODS}

This study was conducted on an exposed rocky platform located at the southern end of the Dwesa Nature Reserve $\left(32^{\circ} 18^{\prime} \mathrm{S}, 28^{\circ} 50^{\prime} \mathrm{E}\right)$ on the southeast coast of South Africa. The infratidal fringe, where Perna perna is most abundant, exhibits a distinct mosaic structure comprising clumps of mussels and tufts of coralline algae interspersed by patches of crustose algae occupied by large patellid limpets (Dye 1992). Within this zone 2 replicate study sites, each encompassing an area of about $20 \mathrm{~m}^{2}$, situated approximately $50 \mathrm{~m}$ apart, were established. At each of these sites triplicate samples of biota, each $100 \mathrm{~cm}^{2}$ in area, chosen haphazardly, were scraped from the centre of both the musseland the algal-dominated microhabitats. Samples, collected at intervals of 4 to $6 \mathrm{wk}$ from March 1991 to March 1992, were preserved in $10 \%$ formalin for subsequent analysis.

In the laboratory plantigrades were extracted as follows: the macrobiota were sorted, teased apart where necessary and then agitated in an ultrasonic bath prior to washing through a series of sieves ranging from $1 \mathrm{~mm}$ to $125 \mu \mathrm{m}$ mesh size. A stereo-microscope was used to examine the material collected on each of the sieves. The shell surfaces and byssal threads of adult mussels were also examined under the microscope. The number of plantigrades found in each sample and their respective lengths, determined by means of an eye-piece micrometer, were recorded. Mussels $\geq 5 \mathrm{~mm}$ total length were measured with vernier calipers.

The plantigrades were divided into 2 sub-groups on the basis of size: mussels of $<500 \mu \mathrm{m}$ shell length were regarded as early plantigrades whereas those from 0.5 to $3.5 \mathrm{~mm}$ shell length were referred to as late plantigrades. These sub-divisions are in accordance with measurements of laboratory-reared Perna perna pediveliger larvae (Siddall 1980), characterizations of Mytilus edulis larvae (Dare 1976, King et al. 1989, Cáceres-Martinez et al. 1993) and the maximum size of plantigrades found on artificial substrata (Lasiak \& Barnard pers, obs.).

Three-way analyses of variance were used to compare densities of both eariy and late plantigrades with respect to sample date, site and type of substratum. To meet the assumptions of constant variance across groups the data were log-transformed prior to the analysis of variance (Sokal \& Rohlf 1981). Comparisons of the size composition of recruits found on filamentous algae and mussel clumps were based on Mann-Whitney $U$-tests and Kolmogorov-Smirnov 2-sample tests performed for separate sampling dates (Conover 1980).

\section{RESULTS}

Mussels of $<500 \mu \mathrm{m}$ were present throughout the study period on both filamentous algae and amidst mussel beds. Mean densities ranged from 1.7 to $47.7100 \mathrm{~cm}^{-2}$ of mussel clumps and from 0 to 41.7 $100 \mathrm{~cm}^{-2}$ of algal turf (Fig. 1). The density of early

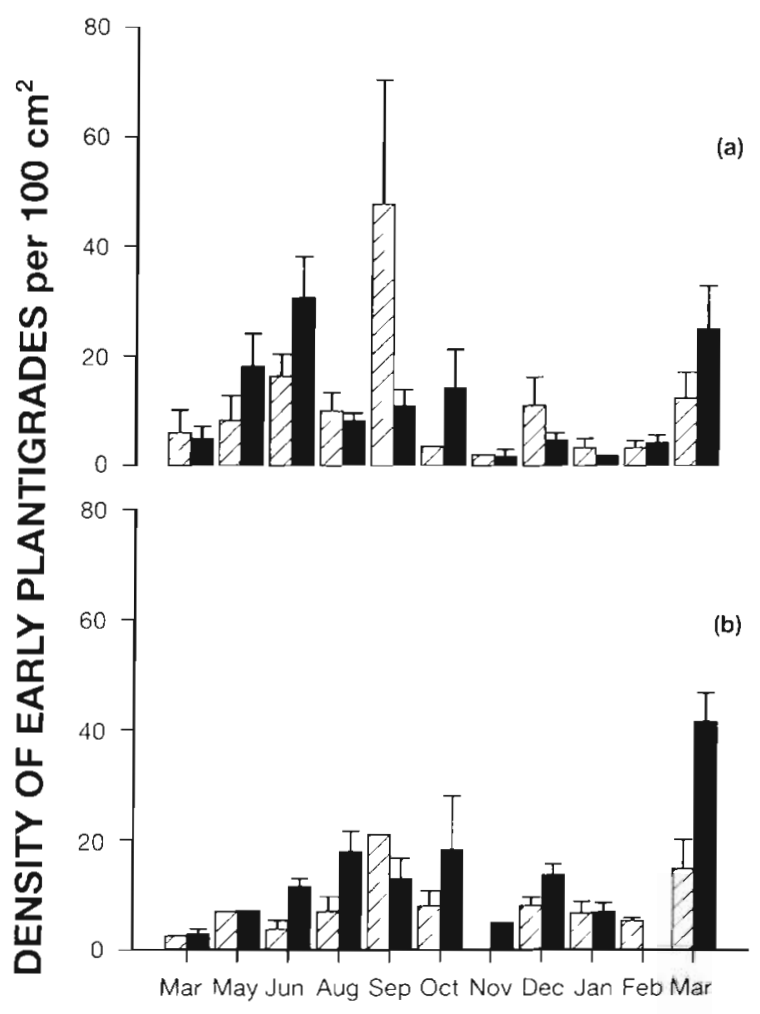

Fig. 1. Perna perna. Mean (+SD) density of early plantigrades (mussels of $<500 \mu \mathrm{m}$ shell length) found per $100 \mathrm{~cm}^{2}$ of (a) mussel and (b) algal substratum. Solid and hatched bars represent data from the 2 study sites 
Table 1 Perna perna. Results of 3-way analyses of variance of log-transformed early plantigrade $(<500 \mu \mathrm{m}$ shell length densities

\begin{tabular}{|lrrrr|}
\hline Source of variation & df & MS & F-ratio & $p$ \\
\hline Date & 10 & 5.170 & 30.151 & $<0.001 \cdot$ \\
Substratum & 1 & 0.109 & 0.638 & 0.427 \\
Site & 1 & 1.481 & 8.634 & $0.004 \cdot$ \\
Date $\times$ Substratum & 10 & 0.938 & 5.469 & $<0.001 \cdot$ \\
Date $\times$ Site & 10 & 1.213 & 7.071 & $<0.001 \cdot$ \\
Substratum $\times$ Site & 1 & 0.501 & 2.924 & 0.091 \\
Date $\times$ Substratum $\times$ Site & 10 & 0.862 & 5.027 & $<0.001 \cdot$ \\
Error & 81 & 0.171 & & \\
'Significant at $\mathrm{p}<0.05$ & & & & \\
\hline
\end{tabular}

plantigrades was generally lower during the late spring and summer months (November to February) and higher during the winter period (June to September). At one of the study sites a marked increase in the density of early plantigrades was evident in March 1992. Three-way analysis of variance indicated significant differences in density of early plantigrades with

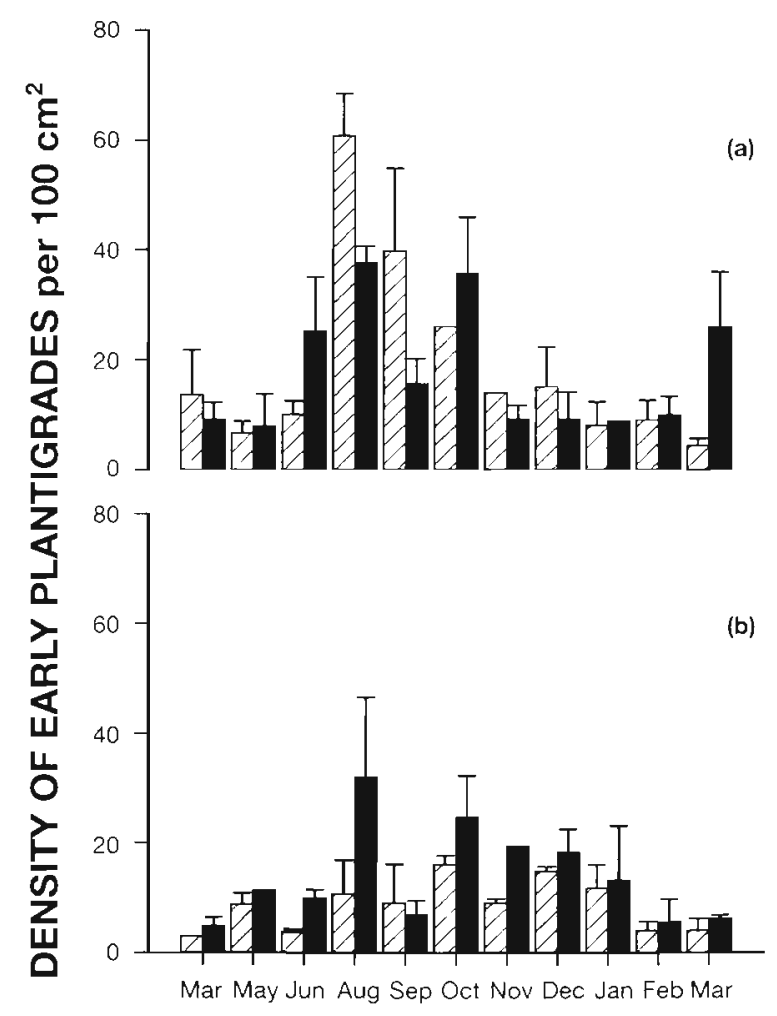

Fig. 2. Perna perna. Mean (+SD) density of late plantigrades (mussels of 0.5 to $3.5 \mathrm{~mm}$ shell length) found per $100 \mathrm{~cm}^{2}$ of (a) mussel and (b) algal substratum. Solid and hatched bars represent data from the 2 study sites
Table 2. Perna perna. Results of 3-way analyses of variance of log-transformed late plantigrade ( $>500 \mu \mathrm{m}$ shell length) densities

\begin{tabular}{|lrrrr|}
\hline Source of variation & d.f & MS & F-ratio & $p$ \\
\hline Date & 10 & 2.590 & 10.101 & $<0.001$. \\
Substratum & 1 & 4.825 & 18.818 & $<0.001 \cdot$ \\
Site & 1 & 1.128 & 4.399 & $0.039 \cdot$ \\
Date $\times$ Substratum & 10 & 1.003 & 3.911 & $<0.001 \cdot$ \\
Date $\times$ Site & 10 & 0.555 & 2.163 & $0.028 \cdot$ \\
Substratum $\times$ Site & 1 & 0.797 & 3.109 & 0.082 \\
Date $\times$ Substratum $\times$ Site & 10 & 0.363 & 1.415 & 0.188 \\
Error & 81 & 0.256 & & \\
& & & & \\
Significant at $\mathrm{p}<0.05$ & & & & \\
\hline
\end{tabular}

respect to both sample date and site, but type of substratum had no significant effect. The interaction terms were all highly significant except that between substratum and site (Table 1).

Temporal variations in the density of late plantigrades recorded on the 2 substrata are shown in Fig. 2. Mean densities varied between 4.3 and $60.7100 \mathrm{~cm}^{-2}$ of mussels and from 3 to 32 per $100 \mathrm{~cm}^{-2}$ of algal turf. Highest densities were observed during the winter months amidst the mussel clumps as opposed to spring and early summer on the algal turf. Three-way analysis of variance indicated that sample date, type of substratum and site all had significant effects on the density of late plantigrades. Date $x$ site was the only significant interaction term (Table 2 ).

The length frequency data for mussels of $<5 \mathrm{~mm}$ shell length found on filamentous algae and amidst mussel clumps are shown in Figs. 3 \& 4 respectively. The fact that there were rarely more than 2 modes evident in the data sets pertaining to the algal substratum, and that only 1 of these was well-defined, probably reflects the scarcity of mussels of $>1 \mathrm{~mm}$ shell length. The rapid decrease in prominence of distinct modes, as observed in the algal turf between October and November, is thus more likely to be indicative of loss of mussels, either as a result of mortality or migration to other substrata, than variable growth increments. Inspection of the corresponding data sets from the mussel clumps does not, however, support the notion of migration from the algal substratum as there is no evidence of an increase in the density of late plantigrades. At the beginning of the study period the length frequency data pertaining to the mussel substratum was bimodal; however, as time progressed a polymodal structure became apparent. The lack of distinct modal progression probably reflects the relatively low densities of mussels recorded and the rapid decline in prominence of the major modes. Comparisons of the 


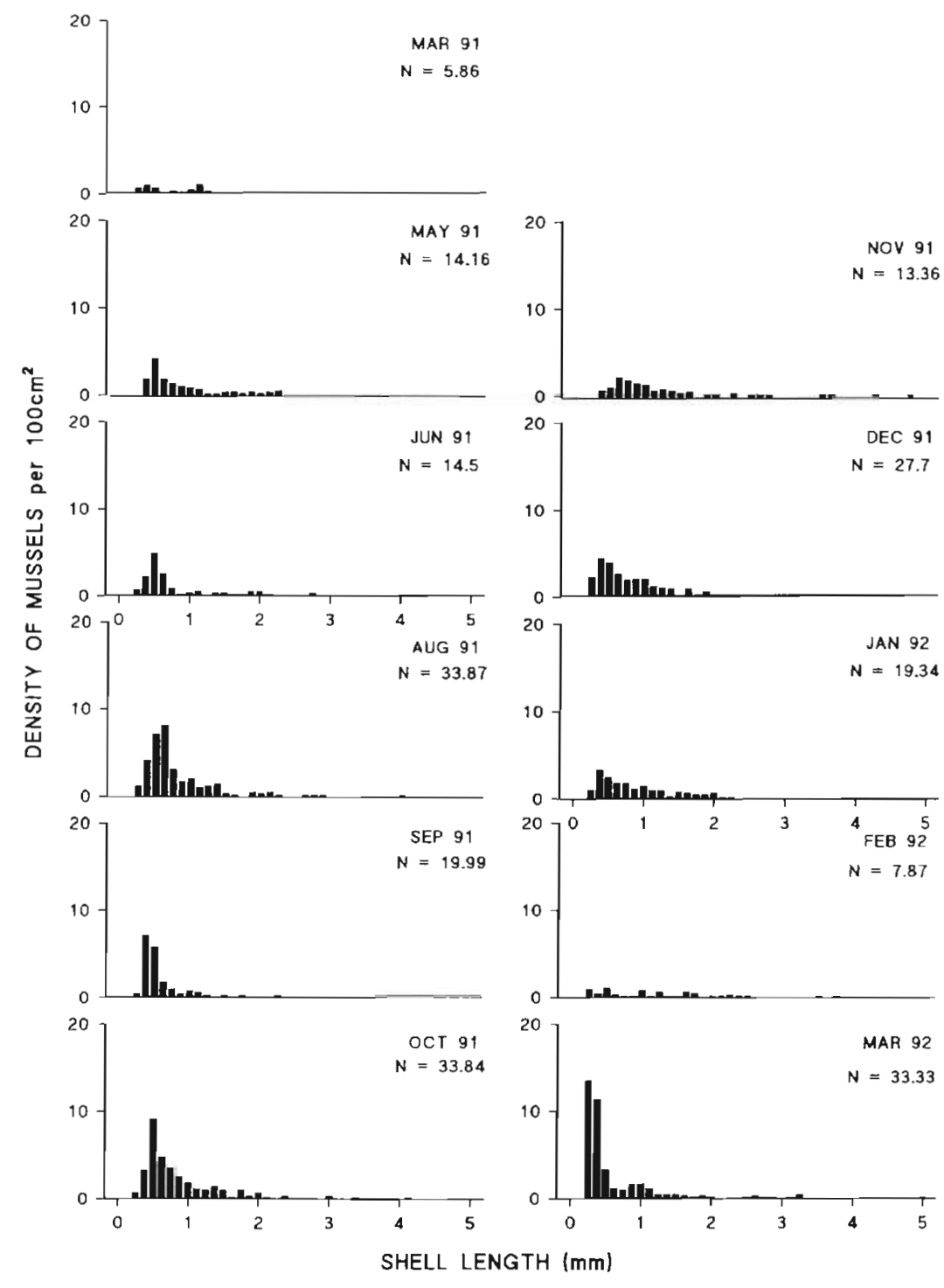

Fig. 3. Perna perna. Size frequency distribution of mussel recruits of $\leq 5 \mathrm{~mm}$ shell length found in association with filamentous algae on each of the 11 sampling dates ( $N$ indicates the mean density of recruits per $100 \mathrm{~cm}^{2}$ of substratum)
Strait, north Wales, took place more than $30 \mathrm{~d}$ after the first definite spatfall on filamentous algae. He also reported marked differences in the size of recruits; the newly settled plantigrades found on filamentous algae varied between 250 and $350 \mu \mathrm{m}$ shell length whereas most of those recruiting into mussel beds were 1.0 to $1.5 \mathrm{~mm}$ and none were $<750 \mu \mathrm{m}$ in length. Similar differences in the sizes of mussels recruiting onto filamentous algae and mussel beds noted elsewhere in Britain (Seed 1969, Dare 1976) provided further support for Bayne's (1964) primary and secondary settlement hypothesis. More recent studies, however, have shown that, in some populations of $M$. edulis, early plantigrades forgo an initial growth phase on filamentous substrata and settle directly onto adult mussel beds (McGrath et al. 1988, King et al. 1990). Bohle (1971) and Kautsky (1982) believe that the absence of mussels of $>400 \mu \mathrm{m}$ shell length in the plankton also casts doubt on the existence of a secondary pelagic phase.

Comparatively little is known about the settlement and recruitment of Perna perna. Carvajal (1969) and Acuña (1977) did not distinguish between primary and secondary settlement nor did they provide an indication of the size of recruits in their studies. Previous South African workers assumed the primary and secondary settlement hypothesis to be universally applicable to all mytilid species. Berry (1978), for example, asserted that primary settle- size of plantigrades found on the 2 substrata revealed significant differences in mean size on just 2 occasions, October and November 1991. Significant differences in overall size composition, however, were evident during these 2 months and on 2 additional occasions (June and August 1991) (Table 3).

\section{DISCUSSION}

Much of the information on the settlement and recruitment of mytilid bivalves pertains to one particular species, Mytilus edulis. Bayne (1964) observed that recruitment of $M$. edulis onto mussel beds in the Menai ment of $P$. perna on filamentous substrata was followed by secondary settlement on established mussel beds. He provided no supporting evidence other than a comment that hydroids and coralline algae were heavily colonized by early plantigrades during winter and spring and that massive settlements resulted in the attachment of late plantigrades to all available hard substrata. Crawford \& Bower (1983) and Hops (1990) simply accepted Berry's (1978) assumptions. The most detailed study hitherto in South African waters is that of Beckley (1979) who observed that the majority of $P$. perna plantigrades found attached to the alga Gelidium pristoides belonged to the 0 to $5 \mathrm{~mm}$ size class. 
On the Transkei coast the recruitment of Perna perna does not appear to conform to the primary and secondary settlement hypothesis. Our results not only revealed the occurrence of plantigrades of $<500 \mu \mathrm{m}$ shell length amidst mussel clumps but also showed that, for most of the study period, there were no significant differences in the size distribution of recruits found on filamentous algae and mussel clumps. Although it is not possible to distinguish post-larvae which may have settled elsewhere at a relatively small size, migrated, and then grown prior to sampling from individuals which have delayed settlement (King et al. 1990), the fact that the modal size of the smaller recruits corresponds with the size of metamorphosed pediveligers $(230 \mu \mathrm{m})$ given by Siddall (1980) indicates recent settlement. These recruits were also of a similar size to most of those obtained from artificial substrata deployed for periods of about 4 wk (Lasiak \& Barnard unpubl.).

Perna perna is known to have a protracted spawning period, lasting from February to September (Lasiak 1986); consequently a prolonged period of recruitment was expected, but not one extending throughout the entire year. The fact that plantigrades of $<500 \mu \mathrm{m}$ shell length occur throughout the year points to immigration of larvae from stocks elsewhere. As the spawning periodicities of $P$. perna populations in adjacent provinces (Berry 1978, Hops 1990, Phillips 1990) appear to be similar to that reported in Transkei, such an explanation seems improbable. In view of the relatively low densities of mussels recorded on the natural substrata, the yearround occurrence of $P$. perna plantigrades of $<500 \mu \mathrm{m}$ shell length is unlikely to reflect the competitive suppression of individuals reported in mytilids elsewhere (Seed 1969, Kautsky 1982). The occurrence of small mussels outside the expected recruitment period could, however, reflect a late settlement of post-larvae and the suppression of growth during unfavourable conditions. The most likely explanation for the apparent discrepancy between the spawning and recruitment periods of $P$. perna is the ability of mussel larvae to delay metamorphosis for several weeks until they come into contact with a suitable substratum (Bayne 1965).

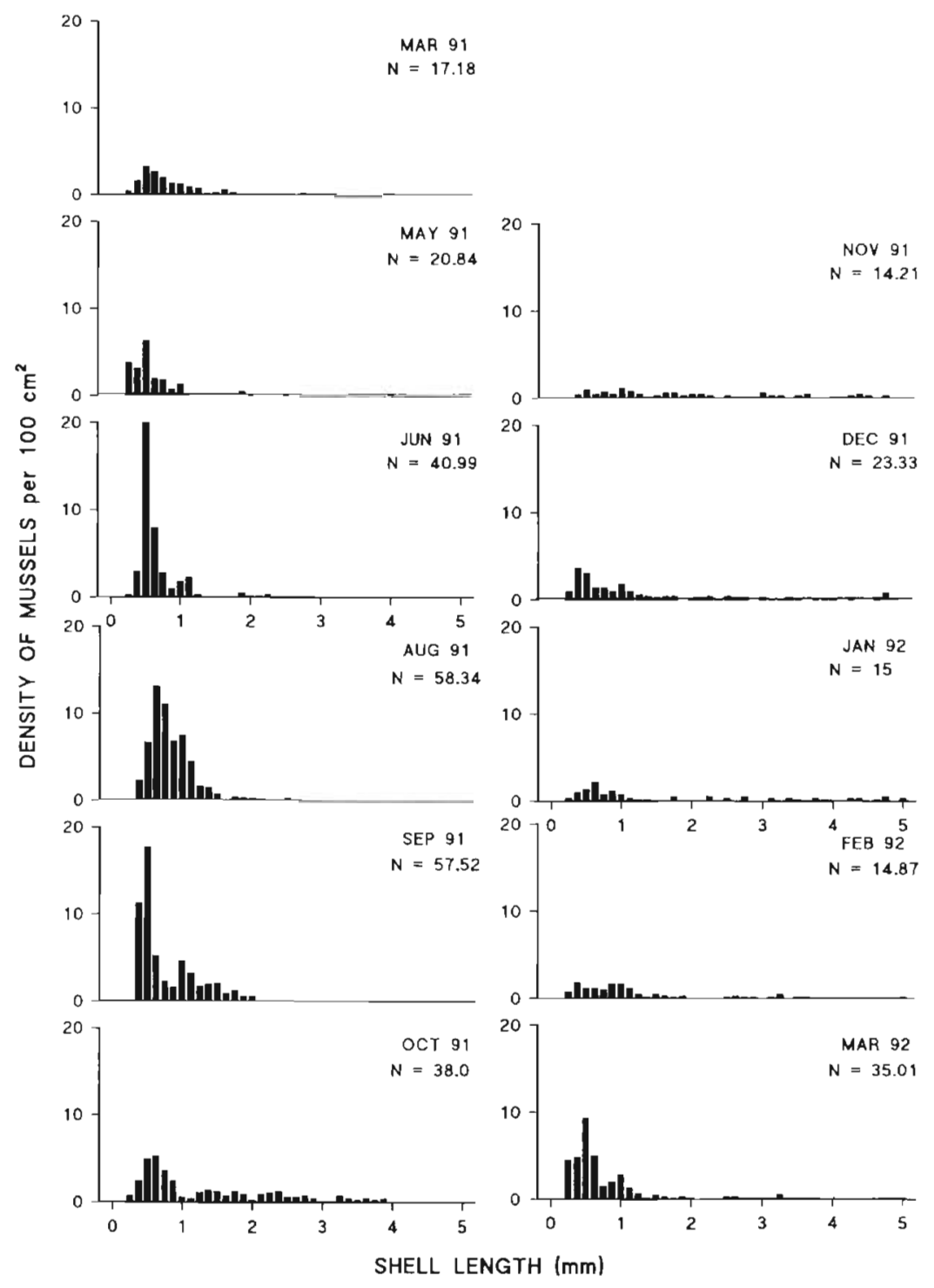

Fig. 4. Perna perna. Size frequency distribution of mussel recruits of $\leq 5 \mathrm{~mm}$ shell length found amidst mussel clumps on each of the 11 sampling dates ( $\mathrm{N}$ indicates the mean density of recruits per $100 \mathrm{~cm}^{2}$ of substratum)

Differences between successive samples represent a balance between the number of larvae settling and the subsequent loss of plantigrades through post-settlement mortality and growth (Seed \& Suchanek 1992). While the apparent lack of significant differences in numbers of early plantigrades recorded on filamentous algae and amidst mussel clumps may suggest that post-larval Perna perna do not discriminate between substrata, the possibility of substratum-related differences in rates of post-settlement mortality can not be discounted. Inspection of successive samples provided relatively little evidence of modal progression. This either reflects a high growth rate or a rapid decrease in the prominence of modes due to considerable post-settlement mortality. 
Table 3. Perna perna. Results of Mann-Whitney $U$-tests and Kolmogorov-Smirnov 2-sample tests comparing the size composition of mussels $(0$ to $5 \mathrm{~mm}$ shell length) recruiting onto filamentous algae and mussel clumps N1: number of recruits found amidst mussel clumps; N2: number of recrults found on filamentous algae; $U$-value: the Mann-Whitney test statistic $T$-value: maximum

vertical distance between distribution functions representing each sample as determined by the Kolmogorov-Smirnov test

\begin{tabular}{|c|c|c|c|c|c|c|}
\hline Sample date & N1 & N2 & $U$-value & Probability & $T$-value & Probability \\
\hline Mar 1991 & 70 & 68 & 2332.0 & 0.838 & 0.116 & 0.754 \\
\hline May 1991 & 92 & 127 & 5318.0 & 0.257 & 0.084 & 0.847 \\
\hline Jun 1.991 & 101 & 234 & 10801.0 & 0.211 & 0.159 & $0.057^{\circ}$ \\
\hline Aug 1991 & 265 & 289 & 40840.0 & 0.176 & 0.116 & $0.048^{\circ}$ \\
\hline Sep 1991 & 325 & 140 & 21489.5 & 0.342 & 0.093 & 0.370 \\
\hline Oct 1991 & 186 & 291 & 33553.5 & $<0.001$ & 0.259 & $<0.001$ \\
\hline Nov 1991 & 69 & 97 & 4015.5 & $0.028^{\circ}$ & 0.267 & $0.007^{\circ}$ \\
\hline Dec 1991 & 156 & 150 & 12431.0 & 0.345 & 0.096 & 0.483 \\
\hline Jan 1992 & 98 & 93 & 4491.5 & 0.864 & 0.097 & 0.767 \\
\hline Feb 1992 & 73 & 63 & 2032.5 & 0.244 & 0.202 & 0.134 \\
\hline Mar 1992 & 110 & 300 & 16344.0 & 0.883 & 0.086 & 0.590 \\
\hline
\end{tabular}

Hops' (1990) observation that a single cohort recruiting onto asbestos settlement plates in the Eastern Cape increased in length from $0.57 \mathrm{~mm}$ in July to $1.57 \mathrm{~mm}$ by October suggests that rapid grow-out is unlikely. This notion is further supported by the observation that juveniles of 5 to $10 \mathrm{~mm}$ total length are abundant only during the summer (Lasiak pers, obs.).

Although the numbers (ca $5000 \mathrm{~m}^{-2}$ ) of Perna perna found recruiting onto natural substrata were similar to those recorded on a subtidal reef in Natal, South Africa, in June 1976, these were considerably lower than the density of recruits (170000 to $\left.210000 \mathrm{~m}^{-2}\right)$ Berry (1978) observed in October 1976. As mytilid bivalves often exhibit spatial and temporal variations in settlement and recruitment intensity (Suchanek 1985), an assessment of which of the above recruitment intensities is the more typical necessitates a long-term monitoring programme. The intense exploitation pressure to which populations of $P$. perna in Transkei are currently subjected combined with the likelihood of recruitment overfishing warrants the urgent implementation of such studies. Consistently low recruitment intensities, as compared with that of other mytilids, may also explain such anomalous attributes of $P$. perna as its lack of competitive dominance and slow recovery from disturbance (Lambert \& Steinke 1986, Lasiak \& Dye 1989, Dye 1992),

Acknowledgements. The authors thank Prof. A. H. Dye and Mr S. Gabula for their assistance in the field. We are also indebted to the University of Transkei Research Committee for funding this project.

\section{LITERATURE CITED}

Acuña, A. C. (1977). Variacion estacional de la fijacion larval del mejillon Perna perna en los bancos naturales de la costa norte del estado sucre, Venzuela. Boln Inst. oceanogr. Univ. Oriente 16: 79-82

Bayne, B. L. (1964). Primary and secondary settlement in Mytilus edulis L. (Mollusca). J. Anim. Ecol. 33: 513-523

Bayne, B. L. (1965). Growth and delay of metamorphosis of the larvae of Mytilus edulis (L.). Ophelia 2: 1-47

Beckley, L. E. (1979). Primary settlement of Perna perna on littoral seaweeds on St Croix Island. S. Afr. J. Zool. 14: $171-172$

Berry, P. F. (1978). Reproduction, growth and production in the mussel Perna perna (L.) on the east coast of South Africa. Invest. Rep. oceanogr. Res. Inst. 48: 1-28

Bohle, B. (1971). Settlement of mussel larvae Mytilus edulis on suspended collectors in Norwegian waters. In: Crisp, D. J. (ed.) Fourth European Marine Biological Symposium. Cambridge University Press, London, p. 63-69

Cáceres-Martinez, J., Robledo, J A. F., Figueras, A. (1993). Settlement of mussels Mytilus galloprovincialis on an exposed rocky shore in Ría de Vigo, NW Spain. Mar. Ecol. Prog. Ser. 93: 195-198

Carvajal, J. R. (1969). Fluctuacion mensual de las larvas y crecimiento del mejillon Perna perna (L) y las condiciones ambientales de la ensenada de Guatapanare, Edo. Sucre. Venezuela. Boln [nst. oceanogr. Univ. Oriente 8: 13-20

Conover, W. J. 1980 Practical nonparametric statistics. John Wiley, New York

Crawford, R. M., Bower, D. F. (1983). Aspects of growth, recruitment and conservation of the brown mussel Perna perna along the Tsitsikamma coast. Koedoe 26: 123-133

Dare, P. J. (1976). Settlement, growth, and production of the mussel, Mytilus edulis L., in Morecambe Bay, England. Fish. Invest., Lond. (II) 28: 1-25

De Blok, J. W \& Geelen, H. J. (1958). The substratum required for the settling of mussels (Mytilus edulis L.) Archs néerl. Zool. 13: 446-460

du Plessis. A. J (1977). Larval development, settlement and growth of the black mussel Choromytilus meridionalis in the Saldahna Bay region. Trans. R. Soc. S. Afr. 42: 303-316

Dye, A. H. (1992). Experimental studies of succession and stability on rocky shore subject to artisanal shellfish harvesting. Neth. J. Sea Res. 30: 209-217

Griffiths, R. J. (1981). Population dynamics and growth of the bivalve Choromytilus meridionalis (Kr.) at different tidal levels. Estuar. coast. Shelf Sci. 12: 101-118 
Hops, J. M. (1990). The effect of industrial and domestic effluents on the settlement, growth, reproduction and mortality of the brown mussel, Perna perna, in the outlet of the Papenskuil river, Algoa Bay, South Africa. M. Sc. thesis, University of Port Elizabeth

Kautsky, N. (1982). Quantitative studies on gonad cycle, fecundity, reproductive output and recruitment in a Baltic Mytilus edulis population. Mar. Biol. 68: 143-160

King, P. A., McGrath, D., Britton, W. (1990). The use of artificial substrates in monitoring mussel (Mytilus edulis L.) settlement on an exposed rocky shore in the west of Ireland J. mar. biol. Ass. U.K. 70: 371-380

King, P. A., McGrath, D., Gosling, E. M. (1989). Reproduction and settlement of Mytilus edulis on an exposed rocky shore in Galway Bay, west coast of Ireland. J. mar. biol. Ass. U.K. 69: 355-365

Lambert, G., Steinke, T. D. (1986). Effects of destroying juxtaposed mussel-dominated and coralline algal communities at Umdoni Park, Natal south coast, South Africa. S. Afr. J. mar. Sci. 4: 203-217

Lasiak, T. A. (1986). The reproductive cycles of the intertidal bivalves Crassostrea cucullata (Born, 1778) and Perna perna Linnaeus, 1758) from the Transkei coast, southern Africa. Veliger 29: 226-230

Lasiak, T A. (1991). Is there evidence of over-exploitation of mussels on the Transkei coast? S. Afr. J. mar. Sci. 10: 299 302

Lasiak, T A., Dye, A. H. (1989). The ecology of the brown mussel Perna perna in Transkei, southern Africa: implications for the management of a traditional food resource.

This article was submitted to the editor
Biol Conserv. 47: 245-257

Maas Geesteranus, R. A. (1942). On the formation of banks by Mytilus edulis L. Archs néerl. Zool. 6: 283-325

McGrath, D., Kung, P. A., Gosling, E. M. (1988). Evidence for direct settlement of Mytilus edulis larvae on adult mussel beds. Mar. Ecol. Prog. Ser. 7· 103-106

Phillips, T (1990). Periodicity and variability in spawnung and recruitment of the intertidal mussel. Perna perna, on the South Eastern Cape coast of southern Africa. Oceans' 90 7th National Oceanographic Conference, San Lameer, South Africa, 25-29 June 1990. Abstract

Seed, R. (1969). The ecology of Mytilus edulis L. (Lamell1branchiatal on exposed rocky shores. I. Breeding and settlement. Oecologia 3: 277-316

Seed. R., Suchanek, T. H. (1992). Population and community ecology of Mytilus, ln: Gosling, E. (ed.) The mussel Mytilus: ecology, physiology, genetics and culture. Elsevier Science, Amsterdam, p. 87-169

Siddall, S. E. (1980). A clarification of the genus Perna (Mytilidae). Bull mar. Sci. 30: 858-870

Siegfried, W. R., Hockey, P. A. R., Crowe, A. A. (1985) Exploitation and conservation of brown mussel stocks by coastal people in Transkei. Environ. Conserv. 12: 303-307

Sokal, R. R., Rohlf, F. J. (1981). Biometry. W. H. Freeman \& Co., San Fransisco

Suchanek, T H. (1985). Mussels and their role in structuring rocky shore communities. In: Moore, P. G. \& Seed, R. (eds.) The ecology of rocky coasts. Hodder \& Staunton, London, p. 70-96

Verwey, J. (1952). De mossel en zijn eisen. Faraday 24: 1-13

Manuscript first received: August 9, 1994

Revised version accepted: January 9, 1995 